\title{
Asmalarda fungal gövde hastalıklarının araştırılmasında farklı inokulasyon yöntemlerinin karşılaştırılması
}

Comparison of different inoculation methods in the investigation of fungal trunk diseases in grapevines

Davut Soner AKGÜL ${ }^{1}$

${ }^{1}$ Çukurova University, Faculty of Agriculture, Department of Plant Protection, Balcalı-Adana, Turkey.

MAKALE BILGISI / ARTICLE INFO

Makale tarihçesi / Article history:

DOI: $10.37908 /$ mkutbd.741812

Geliş tarihi /Received:23.05.2020

Kabul tarihi/Accepted:02.07.2020

\section{Keywords:}

Grapevine, Dactylonectria nacrodidyma, Diaporthe ampelina, Neofusicoccum parvum, Phaeomoniella chlamydospora.

\footnotetext{
Corresponding author: D. Soner AKGÜL

$\bowtie$ : sakgul@cu.edu.tr
}

\section{ÖZET / A B STR A C T}

\begin{abstract}
Aims: Grapevine trunk disease are complex diseases caused by many fungal plant pathogens. In this study, it was aimed to determine the most suitable inoculation method for some fungal pathogens representing four different diseases (Petri and Black Foot, Botryosphaeria and Phomopsis Dieback).
\end{abstract}

Methods and Results: Fungal species Phaeomoniella chlamydospora, Dactylonectria macrodidyma, Neofusicoccum parvum and Diaporthe ampelina were inoculated into dormant canes or green shoots by different inoculation methods. These methods for dormant cuttings were as follows; mycelial agar disc inoculation under bark (a), mycelial agar disc placement onto the top of cuttings (b), xylem injection method (c) and mycelial agar disc inoculation on green shoots (d). After inoculation of the pathogens on cuttings and shoots, they were allowed to grow for 2 months and then lesion lengths on the tissues were measured. As a result, all the pathogens produced lesions on both dormant canes and green shoots with all inoculation methods, but measured lesion lengths differed from the inoculation methods used. The pathogen and inoculation methods matching, in which the longest lesions were formed, were as follows; mycelial agar disc inoculation on green shoots for Diaporthe ampelina (72.2 $\mathrm{mm}$ ), xylem injection method for Dactylonectria macrodidyma and Phaeomoniella chlamydospora (23.0 $\mathrm{mm}$ and $66.1 \mathrm{~mm}$ respectively) and mycelial agar disc inoculation under bark for Neofusicoccum parvum (51.5 $\mathrm{mm})$.

Conclusions: Although different inoculation methods have been used by many researchers to investigate in grapevine fungal trunk diseases, it has been revealed that pathogenicity tests can be performed using one of methods used in this study. In studies with a large number of spore producing species, it has been observed that the xylem injection method would yield more plausible results. It was also found that mycelial agar disc inoculations, under bark or on the top of the cuttings, were more suitable for the species having a strong mycelial growth and pycnidial production. Significance and Impact of the Study: The selection of the inoculation method in a study directly affects the results of that research. It is thought that the results of this study may contribute to the selection of the appropriate inoculation method in researches on grapevine trunk diseases.

Atıf / Citation: Akgül DS (2020) Asmalarda fungal gövde hastalıklarının araştırılmasında farklı inokulasyon yöntemlerinin karşılaştırılması. MKU. Tar. Bil. Derg. 25(2) : 262-270. DOI: 10.37908/mkutbd.741812 


\section{GiRiş}

Asmalarda fungal etmenlerden kaynaklanan gövde hastalıkları, son yıllarda dünya ve ülkemiz bağlarında önemli bir sorun haline gelmeye başlamıştır. Son 50 yılda dünyadaki bağ alanlarının artmasına paralel olarak üretim materyallerinin ülkeler arasında taşınması, makineli budamayla birlikte farklı terbiye sistemlerinin yaygınlaşması ve 1990 'lı yıllardan başlamak üzere sodyum-arsenit, benzimidazol grubu fungisitler ve metil bromidin yasaklanmasıyla, asma gövde hastalıklarının hızla yaygınlaştığı bildirilmiştir (Bertsch ve ark., 2013). Asma gövde hastalıkları uzun vadede ekonomik kayıplara neden olmakta ve bağcllıktan elde edilen kazancı azaltmaktadır. 2013 yılında Brüksel'de yayınlanan bir COST raporuna göre; asma gövde hastalıkları nedeniyle tüm dünyadaki asmaların \%1'inin söküldügü ve yerine yenilerinin dikildiği ifade edilmiş, buna göre yenileme maliyetleri, harcanan zaman, ürün azalışı ve benzer ekonomik kayıpların, dünya genelinde 1.132 milyar Euro civarında olduğu tahmin edilmiştir (Anonymous, 2013).

Bugüne kadar 34 cinse bağlı 133 farklı fungus türünün, asma gövde hastalıklarına neden olduğu tespit edilmiştir (Gramaje ve ark., 2018). Asma gövde hastalıkları içerisinde Esca Sendromu, Botryosphaeria, Eutypa, Phomopsis Geriye Ölüm Hastalıkları, Petri ve Siyah Bacak Hastalıkları şeklinde farklı başlıklar altında gruplandırılmaktadır. Bir grupta yer alan benzer türler birbirine yakın biyolojik döngüye sahip olsalar da, farklı gruplar içerisindeki türlerin biyolojileri birbirinden farklıdır. Örneğin genç asmalarda Siyah Bacak Hastalığı'na yol açan funguslar, Cylindrocarponanamorfları olarak adlandırılan toprak kökenli funguslardır ve bunlar çoğunlukla ürettikleri miselyum, konidiler veya klamidosporları aracılığıyla yayılmaktadır. Diğer taraftan Botryosphaeria, Eutypa, Phomopsis cinslerine bağlı türler, çoğunlukla pikniosporlar ya da peritesyumlardan doğmuş askosporlarıyla diğer asmaları enfekte etmektedirler. Petri Hastalığı etmenlerinin ise daha çok asma üretim materyalleri içerisinde (veya üzerinde) eşeysiz mikrokonidileri, bazen de askosporlarıyla geniş alanlara yayılabildikleri bildirilmiştir (Halleen ve ark., 2006; Mostert ve ark., 2006; Urbez-Torres, 2011).

Son 30 yılda asma gövde hastalıklarıyla ilgili araştırmaların sayısı hızla artmış, bu patojenlerin biyolojileri aydınlatılmış ve filogenetik ayrımlarla neredeyse tamamının taksonomik yerleri belirlenmeye çalışımıştır. Etiyolojik, taksonomik ve epidemiyolojik çalışmalarla birlikte bu hastalıklara neden olan patojenlerin mücadelesiyle ilgili çalışmalar da yürütülmüştür. Bu çalışmalar yürütülürken besi yerinde ya da doğal substratlarda çoğaltılan inokulum farklı yöntemlerle asmalara bulaştırılmış ve virülenslikleri belirlenmiştir. Ancak patojenisite ya da çeşit duyarlılığı testlerinde birçok araştırmacı farklı inokulasyon yöntemlerini kullanmışlardır. Alaniz ve ark., (2007) İspanya'da Cylindrocarpon türlerinin bitki gelişimine etkilerini inceledikleri bir çalışmada 8 aylık, köklendirilmiş 110-R anacının köklerini fungal izolatların spor süspansiyonuna daldırarak inoküle etmişler ve 4 ay sonra kök enfeksiyonları ve sürgün kuru ağırlıklarını incelemişlerdir. Burruano ve ark., (2008) İtalya'nın Sicilya Bölgesi'nde yetiştirdikleri iki yaşındaki Insolina çeşidi asmalarda Lasiodiplodia theobromae'nın hastalık oluşturma gücünü test etmişlerdir. Toprağın $10 \mathrm{~cm}$ üzerinden gövdeye 1-1.5 cm uzunluk ve $5 \mathrm{~mm}$ derinliğinde yaralar açmışlar ve bu noktalara fungusun miselyal agar disklerini inokule ederek 2 ay sonra, odun dokuda oluşan lezyonları değerlendirmişlerdir. Baumgartner ve ark., (2013) bir yaşındaki Chardonnay çeşidi asma fidanlarında Diaporthe ve Phomopsis türlerinin patojenisite çalışmalarını yürütmüşlerdir. Odunsu gövdeye elektrikli matkap ile $2 \mathrm{~mm}$ genişlik ve 3 $\mathrm{mm}$ derinlikte yaralar açarak patojenlerin spor süspansiyonlarından $20 \mu \mathrm{ll}$ enjekte etmişler ve inokulasyondan 1 yıl sonra meydana gelen lezyonları değerlendirmişlerdir. Avustralya'da yapılan diğer bir çalışmada ise Eutypa lata'nın askosporlarından oluşan süspansiyon, $10 \mathrm{~cm}$ uzunluğunda kesilmiş asma kalemlerinin (çeşit Shiraz) tepesine mikropipetle damlatılmış, bu kalemlerin dip kısmı polistren köpüklere saplanarak platform suda yüzdürülmüş ve 4 hafta sonra üstten dibe doğru, odun dokuda oluşan lezyon uzunlukları ölçülmüştür (Ayres ve ark., 2011).

Yukarıda özetlenen çalışmalardan anlaşılacağı gibi asma gövde hastalıklarının araştırılmasında farklı patojenler farklı yöntemlerle inoküle edilmişler ve lezyon uzunlukları değişik zamanlarda ölçülerek değerlendirilmiştir. Asma gövde hastalıklarına neden olan türlerden bazıları (Ör: Eutypa, Botryosphaeria, Neofusicoccum) yapay besi yerinde spor üretebilmeleri için özel koşullar gerekmekte veya sporulasyon çok uzun zaman almaktadır. İnokulum üretimindeki zorlukların yanı sıra bu funguslar odun dokularda geliştiklerinden, lezyon oluşturmaları için uzun bir süreye ihtiyaç duymaktadırlar. Denemelerin kısa sürede doğru bir şekilde yapılabilmesi için farklı inokulasyon yöntemlerinin karşılaştırılması, araştırmaların amacına göre uygun bir yöntemin seçilmesi gerekmektedir. Reis ve ark., (2019) yazmış oldukları derlemede yukarıda bahsedilen metotların yanında kallus kültürü ve yaprak disk inokulasyonlarına da değinmişler ancak oldukça basit bir metot olan tepeden inokulasyona yer 
vermemişlerdir. Bu nedenle ülkemizde yürütülecek çalışmalara katkı sağlayabilmek için hem kolay hem de hızlı bir yöntemin önerilebilmesi amacıyla bu çalışma planlanmıştır. Çalışmada, asma gövde hastalıkları ile yapılacak denemelerde farklı inokulasyon yöntemlerinin karşılaştırılması ve araştırmanın içeriğine göre en uygun yöntemin önerilmesi amaçlanmıştır.

\section{MATERYAL ve YÖNTEM}

\section{Hastalık etmenleri}

$\mathrm{Bu}$ çalışmada Botryosphaeria Geriye Ölüm, Petri Hastalığı, Siyah Bacak Hastalığı ve Ölü Kol Hastalıklarını temsilen her bir fungal patojen türünden birer izolat (daha önce tanısı ve patojenisitesi yapılmış) kullanılmıştır. Söz konusu fungal patojen türler, sırasıyla Neofusicoccum parvum'un Npar2Trs, Phaeomoniella chlamydospora'nun Pch1Trs, Dactylonectria macrodidyma'nın MBAE255 ve Diaporthe ampelina'nın Damp1Trs numaralı izolatlarından oluşmuştur.

\section{Farklı inokulasyon yöntemleri ile fungal patojenlerin inokulasyonu \\ Ksileme enjeksiyon (KSE) yöntemi}

Bu yöntemde, Patates Dekstroz Agar besi yerinde (PDA: Merck) 10-15 gün süreyle geliştirilen fungal kültürlerden $10^{7} \mathrm{spor} / \mathrm{ml}$ konsantrasyonda spor süspansiyonları hazırlanmıştır. Yapay besi yerinde spor oluşturması zor olan türlerin piknidyumları, doğal substratlarından steril bisturi ile alınarak $1.5 \mathrm{ml}$ 'lik steril tüplerdeki distile suya (500 $\mu$ l) bırakılmış, oda sıcaklığında 1 gece bekletildikten sonra 5-6 dk vortekslenmiş ve pikniospor süspansiyonu elde edilmiştir. Ardından pikniospor yoğunluğu yine Thoma Lamı ile $10^{7} \mathrm{spor} / \mathrm{ml}$ 'ye ayarlanmıştır. Bağdaki asmalardan Ocak ayında $30 \mathrm{~cm}$ uzunluğunda, 4-5 gözlü kalemler kesilmiş, bunlar laboratuvara getirilip çeşme suyunda 1 gece tutulmuşlardır. Ertesi gün elektrikli bir matkap ile boğum aralarına $2 \mathrm{~mm}$ çapında ve $5 \mathrm{~mm}$ derinliğinde delikler açılmış, otomatik mikropipetör ile her bir deliğe $10 \mu \mathrm{l}$ konidiyal veya piknidiyal süspansiyon enjekte edilmiştir (Şekil 1). İnokulasyon noktası parafilmle sarıldıktan sonra dormant kalemler, içerisinde yetiştirme harcı (her biri eşit hacimde olmak üzere; torf, talaş, kum, perlit ve toprak) bulunan plastik torbalara dikilmiş ve iklim odasında $\left(25^{\circ} \mathrm{C}\right.$ sıcaklık, $\% 75$ nispi nem, 12 saat aydınlık/12 saat karanlık) 2 ay süreyle gelişmeye bırakılmıştır. Kontrol olarak bırakılan dormant kalemlere sadece steril distile su enjekte edilmiştir. İnokulasyondan 2 ay sonra dormant kalemler bıçakla uzunlamasına kesilmiş, inokulasyon noktasının iç bölgesinde oluşan nekrotik alanların uzunlukları ölçülmüştür. Denemede her bir patojen için tesadüf parselleri deneme deseninde 4 tekerrürlü bir deneme kurulmuş ve her bir tekerrürde 3 kalem olmak üzere toplam 12 asma kalemi kullanılmıştır.

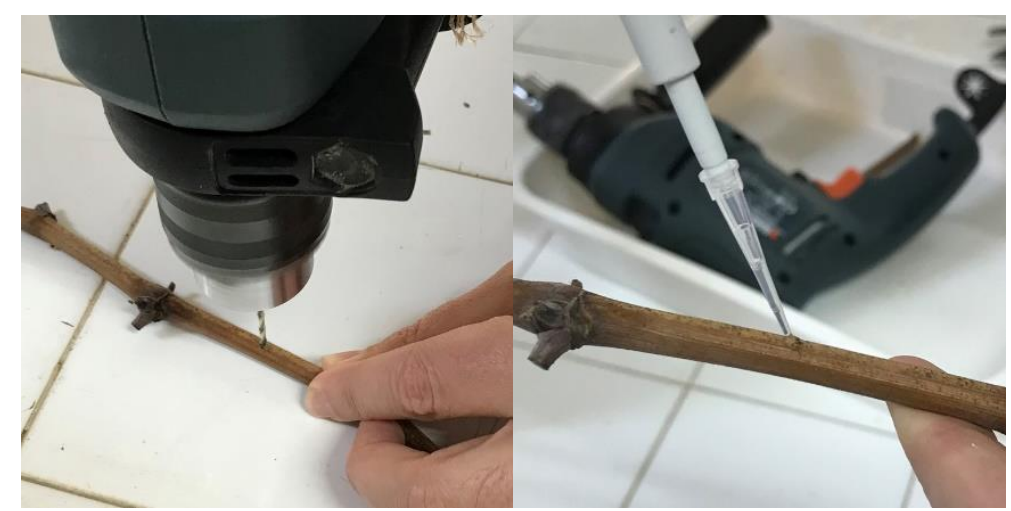

Şekil 1. Dormant asma kalemlerinde patojeninin ksileme enjeksiyonu (Baumgartner ve ark., 2013)

Figure 1. Injection of pathogen into xylem of dormant grapevine cuttings

\section{Yeşil sürgüne disk (YSD) inokulasyonu yöntemi}

PDA besi yerinde 10-15 gün süreyle geliştirilen fungal izolatların miselyal agar diskleri, Mayıs ayında asmaların yeşil sürgünlerine uygulanmıştır. Arazi koşullarında gerçekleştirilen bu uygulamada Kober 5BB/Prima çeşidi asmaların ortalama $1 \mathrm{~cm}$ çapındaki yeşil sürgünlerine, steril bisturi ile $0.5 \mathrm{~cm}$ çapında yüzeysel çizikler yapılarak, bu bölgelere miselyal agar diskleri yerleştirilmiş ve etrafı parafilm ile sarılmıştır. İnokulasyon, asmalardaki dip gözlerden yaklaşık $25-30 \mathrm{~cm}$ uzaklıktaki bir noktada yapılmıştır. Her bir patojen için farklı omcalar seçilmiş ve bir omcadan 4 ayrı yeşil sürgün inoküle edilmiştir (Şekil 2). Her sürgün bir tekerrür olarak kabul edilmiş ve tesadüf blokları deneme deseninde 4 tekerrürlü bir deneme yürütülmüştür. Kontrol olarak ise yeşil sürgünlere sadece fungal kültür içermeyen agar diskleri inokule edilmiştir. Bu işlemden 2 ay sonra inokulasyon noktasındaki parafilm açılıp sürgün üzerinde oluşan 
nekrotik lezyonların uzunlukları ölçülmüş ve kaydedilmiştir.

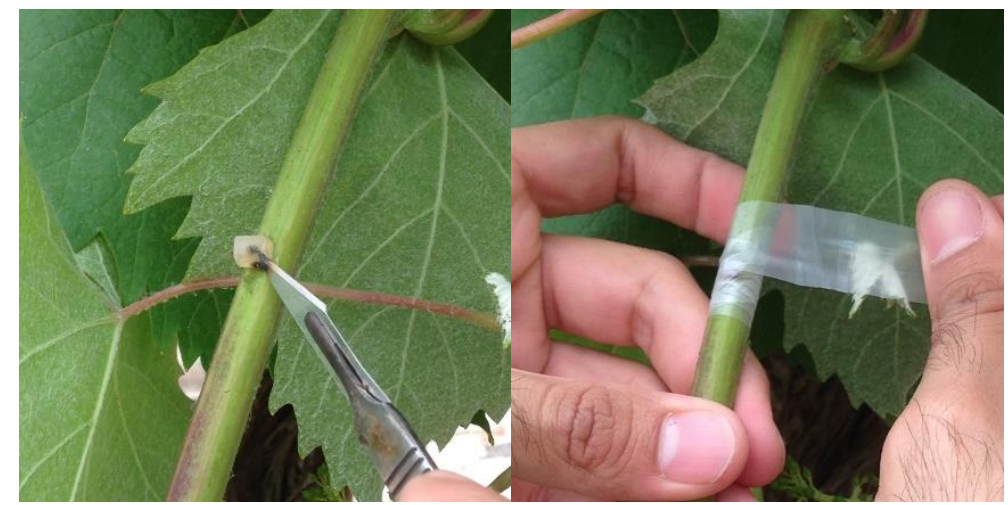

Şekil 2. Yeşil sürgünlere miselyal agar disk inokulasyonu (Rawnsley ve ark., 2004)

Figure 2. Mycelial agar disc inoculation to green soots

\section{Kalemlere tepeden disk (KLTD) inokulasyonu yöntemi}

$\mathrm{Bu}$ yöntemde, dormant asma kalemleri dipten ve tepeden küt kesilmiş, tepe kısmına miselyal agar disk yerleştirilerek streç film ile sarılmıştır. Kalemlerin dip kısmı strafor-köpük plakalara saplandıktan sonra su dolu küvetlerde yüzdürülmüş ve klima odasında büyümeye bırakılmıştır (Şekil 3). Durgun sudaki mikrobiyal kontaminasyonu önlemek ve oksijeni tazelemek için küvetlerdeki su gün aşırı değiştirilmiştir. Kök, sürgün ve yaprak oluşturan asma kalemleri bu şekilde 2 ay süreyle büyütüldükten sonra tepedeki streç film açılmış, kalemler boylamsal olarak bıçakla kesilmiştir. Tepeden dibe doğru oluşan içsel lezyonlar cetvelle ölçülerek kaydedilmiştir. Kontrol olarak tertip edilen kalemlerin uç kısmına ise sadece fungus içermeyen agar diskleri yerleştirilmiştir. Her bir patojen için 12 dormant kalem kullanılmış, 4 tekerrür oluşturulmuş, her tekerrürde 3 kalem yer almıştır.

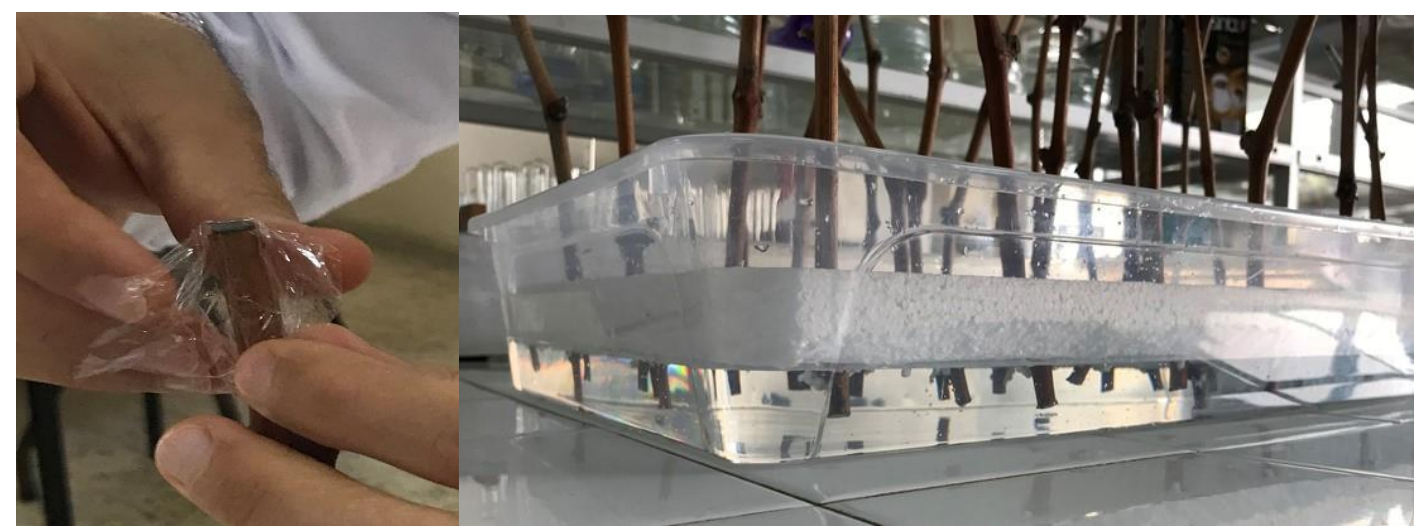

Şekil 3. Dormant kalemlere tepeden miseliyal disk inokulasyonu (Ayres ve ark., 2011)

Figure 3. Mycelial agar disc inoculation to the tops of dormant cuttings

\section{Kabuk altına disk (KAD) inokulasyonu yöntemi}

Kabuk altına miselyal disk inokulasyonunda, dormant kalemlerdeki boğum araları, $5 \mathrm{~mm}$ çaplı mantar delici ile yaralanarak kabuk çıkarılmıştır. Bu noktaya patojenlerin miseliyal agar diskleri yerleştirilmiş ve etrafı parafilm ile sarılmıştır (Şekil 4). İnokule edilen kalemler, içerisinde yetiştirme harcı bulunan poşetlere dikilmiş ve iklim odasında 2 ay süreyle büyütülmüşlerdir. Daha sonra inokulasyon bölgesi bıçakla dikkatlice kazınarak odun doku üzerinde oluşan lezyonların uzunlukları ölçülmüş ve kaydedilmiştir. Bu yöntemde toplam 12 kalem (4 tekerrürlü, her tekerrürde 3 kalem) kullanılmıştır.

\section{Deneme deseni ve istatistik analiz}

Çalışmanın yeşil sürgüne disk inokulasyonu bölümü tesadüf blokları, diğer inokulasyon yöntemlerinin uygulandığı bölümler ise tesadüf parselleri deneme desenine göre kurulmuştur. Dokularda meydana gelen lezyon uzunluklarına varyans analizi yapılmış, ortalamalar arasındaki farklar LSD testine göre \%5'lik hata payı ile değerlendirilmiştir (Gomez ve Gomez, 1984). 


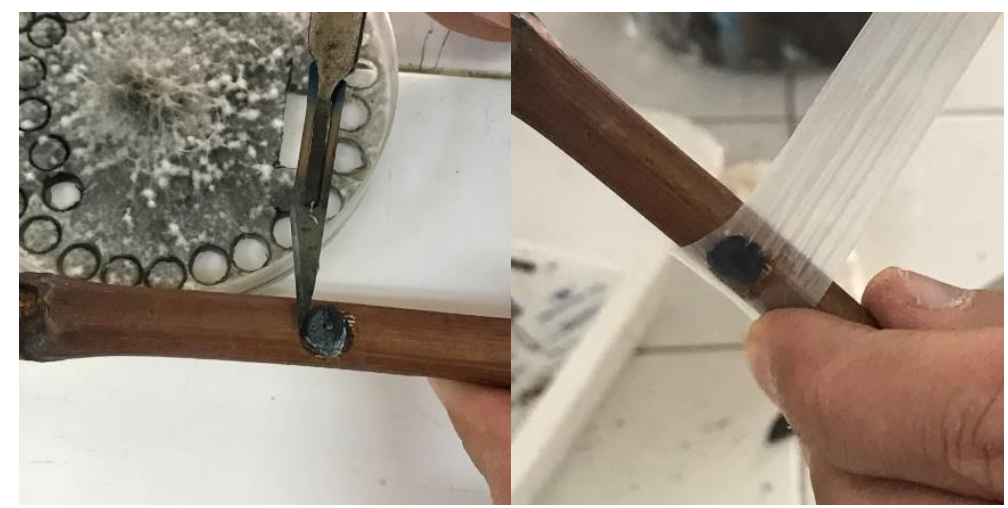

Şekil 4. Kabuk altına miseliyal agar disk inokulasyonu (Sosnowski ve ark., 2005) Figure 4. Under-bark mycelial agar disc inoculation

\section{BULGULAR ve TARTIŞMA}

\section{Farklı inokulasyon yöntemlerinin karşılaştırılması}

Asmalarda ölü kol etmeni Diaporthe ampelina'nın asma bitkilerinde oluşturdukları lezyonların uzunlukları, test edilen inokulasyon yöntemlerine bağlı olarak istatistiksel olarak farklılıklar göstermiştir. En büyük lezyon uzunluğu ortalama $72.2 \mathrm{~mm}$ ile yeşil sürgüne miseliyal agar disk inokulasyon yönteminden elde edilirken bunu 57.8 mm'lik ortalama lezyon uzunluğuyla kabuk altına miseliyal agar disk inokulasyonu takip etmiş ve en uzun lezyon oluşturan ikinci uygulama olmuştur. Ksileme enjeksiyon ve kalemlere tepeden agar disk yöntemlerinde en düşük lezyon uzunluğu (sırasıyla 35.8 $\mathrm{mm}$ ve $33.8 \mathrm{~mm}$ ) saptanırken, bu uygulamalar arasında istatistiki olarak fark saptanmamıştır (Şekil 5).

Fidanlar ve genç asmalarda siyah bacak hastalığına yol açan Dactylonectria macrodidyma dormant patojeni asma kalemlerine inokule edildikten 2 ay sonra en uzun lezyon oluşumu ksileme enjeksiyon yönteminde (23.0 $\mathrm{mm}$ ) gözlenirken, bu yöntem ile kabuk altına miseliyal agar disk inokuasyon yöntemi $(13.4 \mathrm{~mm})$ istatistiki olarak aynı grupta yer almıştır. En düşük lezyon uzunluğu Kalemlere Tepeden Agar Disk ve Yeşil Sürgünlere Agar Disk inokülasyon yöntemlerinde (12.0 mm ve $11.3 \mathrm{~mm}$ ) saptanmıştır (Şekil 5).

Phaeomoniella chlamydospora ile asma dokularına yapılan farklı inokulasyonlarda, D. macrodidyma'da olduğu gibi en uzun lezyon uzunluğu, ksileme enjeksiyon yönteminde $(66.1 \mathrm{~mm})$ elde edilmiş ve bu yöntemi kalemlere tepeden agar disk inokulasyon yöntemi (43.2 $\mathrm{mm}$ ) takip etmiştir. Bu patojenin inokülasyonundaki en düşük lezyon uzunluğu yeşil sürgünlere agar disk inokülasyonu ve kabuk altına miseliyal agar disk inokülasyonu yöntemlerinde (21.8 $\mathrm{mm}$ ve $20.3 \mathrm{~mm}$ ) saptanmış, ancak bu uygulamalar arasında istatistiksel anlamda bir fark saptanmamıştır (Şekil 5).

Neofusicoccum parvum'un asma dokularına dört farklı şekilde inoküle edilerek, patojenin 2 ay süreyle inkübe edilmesiyle, istatistiksel olarak yine farklı lezyon uzunlukları elde edilmiştir. Bu yöntemler içerisinde en uzun lezyon uzunluğu $51.5 \mathrm{~mm}$ ile kabuk altına miseliyal agar disk inokulasyonu yönteminde elde edilmiştir. Buna karşın en kısa lezyon uzunluğu 17.8 mm ile kisleme enjeksiyon yönteminde elde edilmiştir. Yeşil sürgünlere agar disk ile kalemlere tepeden agar disk inokülasyon yöntemlerinde asma dokularında birbirine yakın lezyon uzunlukları (sırasıyla 41.5 ve $42.7 \mathrm{~mm}$ ) elde edilmiş ve her iki yöntem istatistiksel olarak aynı grupta yer almıştır (Şekil 5). Tüm denemelerde steril agarın inokule edildiği kontrol uygulamalarında gerçek anlamda herhangi bir lezyon oluşmazken, uygulamaların birbiri ile olan farklarını ortaya koymak için kontrol değerleri varyans analizlerine alınmamıştır.

Neofusicoccum parvum'un asmada odun dokusunda ve yeşil sürgünlerde kolaylıkla gelişip ilerleyen bir tür olduğu, salgıladığı çeşitli toksinlerle doku ölümlerine ve sonrasında kahverengi lezyonlara neden olduğu bildirilmiştir (Abou-Mansour ve ark., 2015). Kurt ve ark. (2020) tarafından yapılan çalışmada Botryosphaeriaceae familyasına bağlı bir diğer önemli tür olan Botryosphaeria dothidea'nın ceviz ağaçlarında gövde kanseri hastalığına neden olduğu, hastalıklı bitkilerden elde edilen izolatların sağlıklı ceviz ağaçlarından kesilen $1.5-2 \mathrm{~cm}$ çaplı ve $20 \mathrm{~cm}$ uzunluğundaki dallarına yapılan disk inokulasyon yöntemi sonucunda tipik hastalık belirtileri oluşturduğu, inokulasyon noktalarından patojenin yeniden başarılı bir şekilde elde edildiği bildirilmiştir. Yine Botryosphaeriaceae familyasına bağlı türlerin iletim demetlerinde miselyum halinde ilerlediği ancak bitki materyallerinin dış yüzeyinde piknidyum oluşturduğu bilinmektedir. Bu olayda ise doku dışındaki oksijen miktarı ve ışığın etkili olduğu bildirilmektedir (Burgess ve ark., 2005). Çalışmada N. parvum izolatında en uzun lezyon uzunluğunun, kabuk altına yapılan inokulasyonlarda meydana gelmesinin bu olaylarla ilişkili 
olabileceğini göstermektedir. Nitekim Amponsah ve ark. (2008), Botryosphaeriaceae türlerini sporlandırmak için yaptıkları bir çalışmada, inokule edilmiş yeşil sürgünlerden 12-14 gün sonra piknidyum elde edildiğini ve bu yöntemin laboratuvar şartlarında çeşitli besi ortamlarında yapılanlara göre daha verimli olduğunu ifade etmişlerdir. Arazi koşullarında yeşil sürgünlere yapılan inokulasyon, kabuk altına yapılan inokulasyona göre daha kısa lezyonlar oluşturmuştur. Bu olay yeşil sürgünlerin patojene olan dayanıklılığı ile ilgili olabilir. Srivastava ve ark. (2013) asma dokularında sentezlenen fenolik bileşiklerin, laboratuvar koşullarında Botryosphaeriaceae türlerinin gelişimini baskıladığını bulmuşlardır. Bu bileşikler patojendeki laccase ve pektinaz enzimlerinin oluşumunu azaltarak, bu türlerdeki miseliyal büyümeyi olumsuz etkilemiştir. Yeşil sürgünlerdeki fenolik madde miktarının, odunsu dokulardakine göre daha yüksek düzeyde olduğu göz önünde bulundurulursa, lezyon uzunluğunun neden daha kısa olduğuna açıklık getirilebilir. Kalemlere tepeden agar disk inokulasyonu yönteminde, kabuk altına yapılan miseliyal agar disk inokulasyonu yöntemine göre daha kısa lezyon uzunluğu elde edilmiştir. Amponsah ve ark., (2012) Neofusicoccum luteum ile inokule edilen asma kalemlerinde, patojenin dokulardaki ilerleyişini araştırmışlar ve akropetal yöndeki ilerleyişin bazipetal yöne göre daha hızlı olduğunu tespit etmişlerdir. Elde ettiğimiz sonuçların bu olayla ilişkili olduğu düşünülmektedir. Ancak patojenin ksileme inokulasyonunda yine akropetal taşınma söz konusu olsa da, 2 mm'lik matkap tığının açtığı yaraya ancak düşük miktarda piknidial süspansiyon koyulabilecektir. Denemelerde ksileme enjeksiyon yönteminde en kısa lezyon uzunluğunun elde edilmesi buna bağlanabilir.
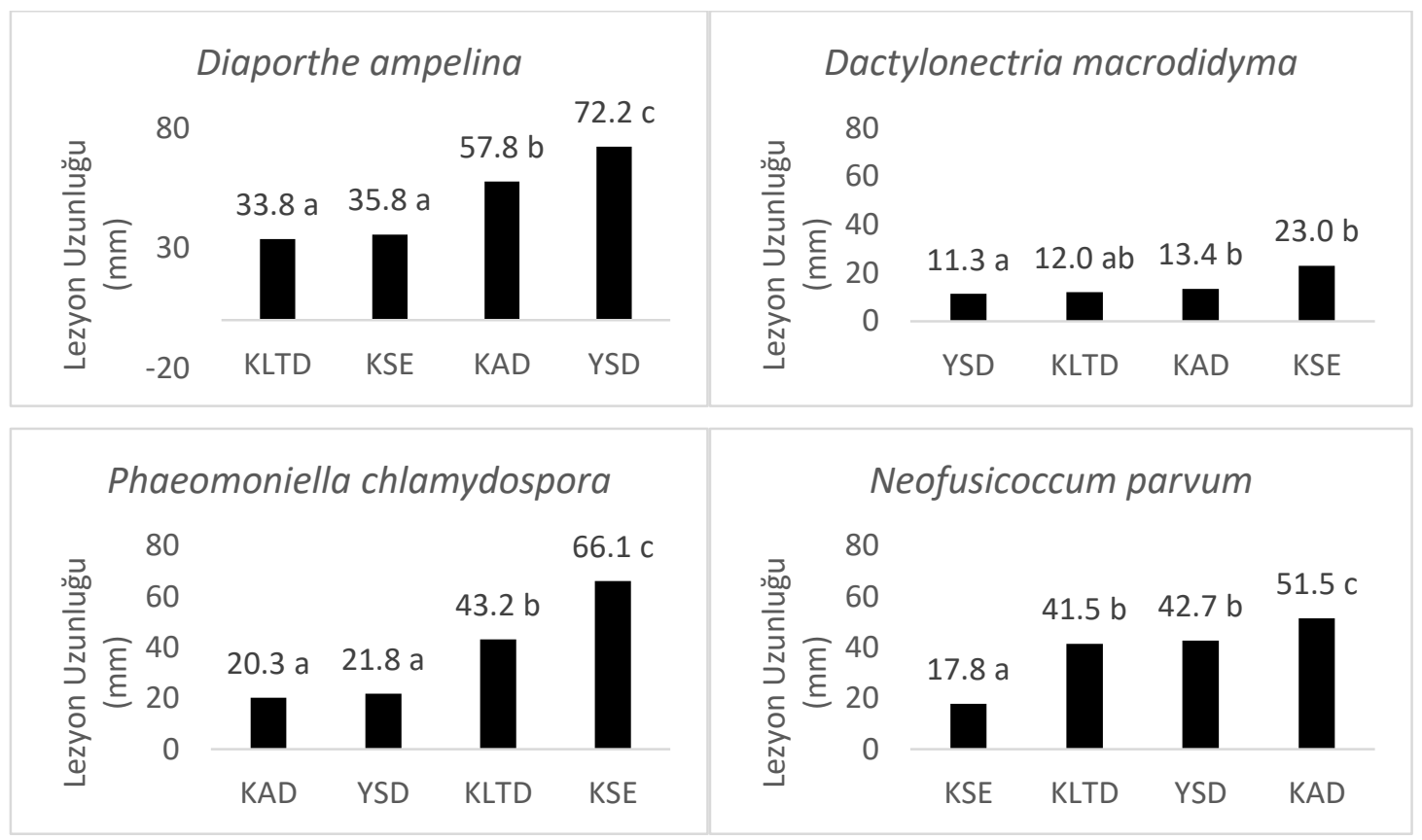

Şekil 5. Farklı inokulasyon yöntemleriyle dormant kalemler ve yeşil sürgünlerde ölçülen lezyon uzunlukları (mm). KAD: Kabuk altına disk, YSD: Yeşil Sürgünlere Disk, KLTD: Kalemlere Tepeden Disk, KSE: Ksileme Enjeksiyon yöntemleri

Figure 5. Lesion lengths measured on dormant cuttings and green shoots with different inoculation methods $(\mathrm{mm})$. KAD: Mycelial discs under-bark of the cuttings, YSD: Mycelial discs on the green shoots, KLTD: Mycelial disc on the top of cuttings, KSE: Xylem injection into the cuttings

Dactylonectria cinsi fungusların söz konusu olduğu durumlarda ksilem enjeksiyonu yönteminde en uzun lezyon uzunluğunun elde edilmesi, patojenin daha çok iletim demetlerinde faaliyet göstermesi ile ilişkili olabilir. Dactylonectria cinsinin, filogenetik açıdan Fusarium cinsi funguslarla yakın olduğu, bol miktarda makro ve mikrokonidi ürettikleri bildirilmiştir (Booth ve Stover, 1974). Üretilen mikrokonidilerin su hareketi ile iletim demetleri içerisinde akropetal yönde taşınması sayesinde, ksileme enjeksiyon ile en uzun lezyon uzunluğu elde edilmesi açıklanabilir. Bu patojenle, kabuk altına ve kalemlere tepeden agar disk inokulasyonu 
yönteminin ksilem enjeksiyonu yöntemi kadar başarılı olmamasının yine bu olayla ilişkili olduğu düşünülmektedir. Ayrıca, Dactylonectria macrodidyma'nın arazi koşullarında yeşil sürgünlere inokule edilmesiyle en kısa lezyonların ölçülmesi yine konukçunun fizyolojik durumuyla bağlantılı olabileceğini akla getirmektedir.

Phaeomoniella chlamydospora ile yapılan inokulasyon çalışmalarında, 2 aylık sürede en uzun lezyon uzunluğunun elde edildiği yöntem yine ksileme enjeksiyon yöntemi olmuştur. Bunun nedeninin yine Dactylonectria macrodidyma'da açıklanan nedenlerle bağlantılı olabileceği düşünülmektedir. Ancak Phaeomoniella chlamydospora patojeni kabuk altına inokule edildiğinde ortalama lezyon uzunluğunun en fazla $20.3 \mathrm{~mm}$ olarak ölçülmesi, etmenin yavaş gelişimi ile ilişkili olabilir. Crous ve Gams (2000), yürüttükleri bir çalışmada $P$. chlamydospora'nın malt extrakt agar üzerinde $25^{\circ} \mathrm{C}$ sıcaklık ve 8 günlük inkübasyon sonunda 5-6 mm'lik koloni çapı oluşturduğunu bildirmişlerdir. Dolayısıyla çalışmada elde edilen odun dokusu üzerindeki en fazla 20.3 mm'lik lezyon uzunluğu kabul edilebilir seviyededir. Kalemlere tepeden agar disk inokulasyon yöntemi ile elde edilen lezyon uzunluğunun ksileme enjeksiyon yönteminden sonra gelmesi, patojenin ürettiği çok küçük boyutlardaki mikrokonidiler nedeniyle olabileceği ve bazipetal yönde taşınmasına olanak sağlanabileceği düşünülmektedir.

Diaporthe ampelina'da ise en çabuk ve bariz sonuç veren yöntem, yeşil sürgüne miseliyal agar disk inokulasyon yöntemi olmuştur. Bilinildiği üzere bu türün arazi koşullarındaki ilk enfeksiyonları, sürgünlerin $3-5 \mathrm{~cm}$ olduğu dönemden başlamakta ve sürgün kabuğunun odunlaşmasına kadar devam etmektedir. $D$. ampelina'nın yeşil sürgünlerde hızlı gelişimi patojenin doğasıyla ilişkili olabilir. Son yıllarda Diaporthe cinsinin asma gövde hastalıkları patojenlerine dahil edildiği görülse de birçok kültür bitkisinde bu funguslar meyve sap ucu çürüklüğüne de neden olduğu bildirilmiştir (Lim ve ark., 2019). Buna dayanarak bu patojenlerin daha çok su içeriği yüksek, gevrek dokularda faaliyete başladığı düşünülmektedir.

Bu çalışmada farklı fungal patojenlerin asma bitkilerinde farklı şekilde inokule edildiğinde değişik lezyon uzunluklarına ulaşılabileceği ve yılın her mevsiminde patojenisite testlerinin rahatlıkla yapılabileceği doğrulanmıştır. Odun dokusu ya da toprak kökenli patojen olup olmadığına bakılmaksızın, tüm patojenler Prima çeşidi asma kalemlerinde ya da yeşil sürgünlerinde lezyonlar oluşturmuştur. Her patojen için tertip edilen kontrol uygulamalarında, steril agar inokule edilen bölgelerde az da olsa renk değişiklikleri görülürken bunların gerçek lezyonlar olmadığı anlaşılmıştır. Patojenisite testinden başka, çeşit duyarlılı̆̆ veya sıcak su uygulamaları üzerine yapılacak araştırmalarda bazı yöntemlerin daha uygun, bazılarının ise pek uygun olmadığı ve fungus türlerinin doğasına göre inokulasyon yöntemlerinin tercih edilmesi gerektiği kanısına varılmıştır. Özellikle mikrokonidi oluşturan türler için ksileme enjeksiyon yönteminin daha gerçekçi sonuçlar vereceği düşünülmektedir. Kalemlere tepeden disk inokulasyon yöntemi, sınırlı alanda çok sayıda deneme kurma olanağı sunmakta ve bu yöntem sayesinde çok sayıda izolatın veya asma çeşidinin test edilebileceği açığa çıkmaktadır.

\section{ÖZET}

Amaç: Asma gövde hastalıkları, birçok fungal bitki patojeninin neden olduğu kompleks hastalıklardır. Bu çalışmada dört farklı hastalığı (Petri ve Siyah Bacak Hastalığı, Botryosphaeria ve Phomopsis Geriye Ölüm Hastalıkları) temsil eden bazı fungal patojenler için en uygun inokulasyon yönteminin saptanması amaçlanmıştır.

Yöntem ve Bulgular: Phaeomoniella chlamydospora, Dactylonectria macrodidyma, Neofusicoccum parvum ve Diaporthe ampelina türü funguslar dormant asma kalemlerine veya yeşil sürgünlere farklı yöntemlerle inokule edilmişlerdir. Dormant kalemlere uygulanan yöntemler; a) kabuk altına miselyal agar disk inokulasyonu, b) tepeden agar disk inokulasyonu, c) ksileme enjeksiyon yöntemi ve d) yeşil sürgünlere agar disk inokulasyonudur. Patojenlerin kalemler ve yeşil sürgünlere inokulasyonunu takiben 2 ay süreyle gelişmelerine izin verilmiş ve sonra dokularda oluşan lezyon uzunlukları ölçülmüştür. Sonuçlara göre tüm patojenler tüm inokulasyon yöntemleriyle, hem dormant kalemler hem de yeşil sürgünler üzerinde lezyonlar meydana getirmiş ancak ölçülen lezyon uzunlukları kullanılan yöntemlere göre farklıık göstermiştir. En uzun lezyonların oluştuğu patojen ve inokulasyon metodu eşleşmesi şu şekilde gerçekleşmiştir; Diaporthe ampelina için yeşil sürgüne miseliyal agar disk inokulasyonu $(72.2 \mathrm{~mm}), \quad D$. macrodidyma ve $P$. chlamydospora için ksileme enjeksiyon (sırasıyla 23.0 ve $66.1 \mathrm{~mm}$ ) ve Neofusicoccum parvum için kabul altına miseliyal agar disk inokulasyonu (51.5 mm).

Genel Yorum: Asmalarda fungal gövde hastalıklarının araştırılmasında birçok araştırmacı tarafından farklı inokulasyon yöntemleri kullanılsa $\mathrm{da}$, patojenisite testlerinin bu çalışmada denenen yöntemlerden herhangi biri ile yapılabileceği ortaya koyulmuştur. Çok 
sayıda spor üreten türlerle yapılan çalışmalarda, ksileme enjeksiyon yönteminin daha makul sonuçlar vereceği görülmüştür. Miselyal gelişimi güçlü ve piknit üreten türler için ise kabuk altına ya da tepeden agar disk inokulasyon yöntemlerinin daha uygun olduğu anlaşılmıştır.

Çalışmanın Önemi ve Etkisi: Bir araştırmada, inokulasyon yönteminin seçimi o araştırmanın sonuçlarını doğrudan etkilemektedir. Bu çalışmanın sonuçlarının, asma gövde hastalıkları ile yapılacak araştırmalarda uygun bir inokulasyon yönteminin seçimine yardımcı olabileceği düşünülmektedir.

Anahtar Kelimeler: Asma, Dactylonectria nacrodidyma, Diaporthe ampelina, Neofusicoccum parvum, Phaeomoniella chlamydospora.

\section{TEŞEKKÜR}

Bu çalışma Çukurova Üniversitesi, Bilimsel Araştırma Birimi tarafından FBA-2018-10561 nolu proje ile desteklenmiştir. Çalışmayı finansal olarak destekleyen Çukurova Üniversitesi Rektörlüğü ve Bitki Koruma Bölümü Başkanlığına teşekkür ederiz.

\section{ÇIKAR ÇATIŞMA BEYANI}

Yazar(lar) çalışma konusunda çıkar çatışmasının olmadığını beyan eder.

\section{ARAŞTIRMACILARIN KATKI ORANI BEYANI}

Yazarlar çalışmaya eşit oranda katkı sağlamış olduklarını beyan eder.

\section{KAYNAKLAR}

Abou-Mansour E, Debieux J, Ramirez-Suero M, BenardGellon M, Magnin-Robert M, Spagnolo A, Chong J, Farine S, Bertsch C, L'Haridon F, Serrano M, Fontaine F, Rego C, Larignon P (2015) Phytotoxic metabolites from Neofusicoccum parvum, a pathogen of Botryosphaeria dieback of grapevine. Phytochemistry 115: 207-215.

Alaniz S, Leon M, Vicent A, Garcia-Jimenez J, AbadCompos M, Armengol J (2007) Characterisation of Cylindrocarpon species associated with black foot disease of grapevine in Spain. Plant Dis. 91: 11871193.

Amponsah NT, Jones EE, Ridgway HJ, Jaspers MV (2008) Production of Botryosphaeria species conidia using grapevine green shoots. N. Z. Plant Prot. 61: 301-305.

Amponsah NT, Jones EE, Ridgway HJ, Jaspers MV (2012) Susceptibility of grapevine tissues to Neofusicoccum luteum conidial infection. Plant Pathol. 61: 719-729.
Anonymous (2013) Technical Report, COST 017/13. Brussels, Belgium: Memorandum of understanding for the implementation of a European concerted research action designated as COST Action FA1303: Sustainable control of grapevine trunk diseases.

Ayres M, Sosnowski M, Wicks T (2011) A rapid technique for evaluating treatments for Eutypa dieback control. Wine and Viticulture J. 26: 50-53.

Baumgartner K, Fujiyoshi PT, Travodon R, Castlebury LA, Wilcox WF, Rolshausen PE (2013) Characterization of species of Diaporthe from wood cankers of grape in Eastern North American vineyards. Plant Dis. 97: 912920.

Bertsch C, Ramirez-Suero M, Magnin-Robert M, Larignon P, Chong J, Abou-Mansour E, Spagnolo A, Clement C, Fontaine $F(2013)$ Grapevine trunk diseases: complex and still poorly understood. Plant Pathol. 62: 243265.

Booth C, Stover RH (1974) Cylindrocarpon musae sp. nov., commonly associated with burrowing nematode (Radopholus similis) lesions on bananas. Trans. Br. Mycol. Soc. 63: 503-507.

Burgess TI, Barber PA, Hardy GES (2005) Botryosphaeria spp. associated with eucalypts in Western Australia, including the description of Fusicoccum macroclavatum sp. nov. Australas. Plant Pathol. 34: 557-567.

Burruano S, Mondello V, Conigliaro G, Alfonzo A, Spagnolo A, Mugnai L (2008) Grapevine decline in Italy caused by Lasiodiplodia theobromae. Phytopathol. Mediterr. 47: 132-136.

Crous PW, Gams W (2000) Phaeomoniella chlamydospora gen. et comb. nov., a causal organism of Petri grapevine decline and esca. Phytopathol. Mediterr. 39: 112-118.

Gomez KA, Gomez AA (1984) Statistical Procedures for Agricultural Research. Wiley Interscience, Canada. 680p.

Gramaje D, Urbez-Torres JR, Sosnowski MR (2018) Managing grapevine trunk diseases with respect to etiology and epidemiology: current strategies and future prospects. Plant Dis. 102: 12-39.

Halleen F, Fourie PH, Crous PW (2006) A review of black foot disease of grapevine. Phytopathol. Mediterr. 45: 55-67.

Kurt Ş, Soylu S, Uysal A, Soylu EM, Kara M (2020) Ceviz gövde kanseri hastalığ etmeni Botryosphaeria dothidea'nın tanılanması ve bazı fungisitlerin hastalık etmenine karşı in vitro antifungal etkinliklerinin belirlenmesi. MKU. Tar. Bil. Derg. 25(1): 46-56. 
Lim L, Mohd MH, Zakaria L (2019) Identification and pathogenicity of Diaporthe species associated with stem end rot of mango (Mangifera indica). Eur. J. Plant Pathol. 155: 687-696.

Mostert L, Halleen F, Fourie P, Crous PW (2006) A review of Phaeoacremonium species involved in Petri disease and esca of grapevines. Phytopathol. Mediterr. 45: 12-29.

Rawnsley B, Wicks TJ, Scott ES, Stummer BE (2004) Diaporthe perjuncta does not cause Phomopsis cane and leaf spot disease of grapevine in Australia. Plant Dis. 88: 1005-1010.

Reis $\mathrm{P}$, Pierron $\mathrm{M}$, Larignon $\mathrm{P}$, Lecomte $\mathrm{P}$, Abou-Mansour E, Farine S, Bertsch C, Jacques A, Trotel-Aziz P, Rego $C$, Fontaine $F(2019)$ Vitis methods to understand and develop strategies for diagnosis and sustainable control of grapevine trunk diseases. Phytopathology 109: 916-931.
Srivastava P, Andersen PC, Marois JJ, Wright DL, Srivastava M, Harmon PF (2013) Effect of phenolic compounds on growth and ligninolytic enzyme production in Botryosphaeria isolates. Crop Prot. 43: 146-156.

Sosnowski M, Lardner R, Wicks T, Scott E (2005) A rapid metod of screening grapevine cultivars for susceptibility to Eutypa dieback. The Australian and New Zealand Grapegrower \& Winemaker 2: 14-16.

Urbez-Torres JR (2011) The status of Botryosphaeriaceae species infecting grapevines. Phytopathol. Mediterr. 50: 5-45. 